Artikel Penelitian

\title{
Pengaruh Pajanan Auditorik Kombinasi Gelombang Monoton dan Ritmis terhadap Ekspresi Postsynapticdensity-95 Hipokampus Neonatus Ayam
}

\author{
Frisca Angreni, ${ }^{1,3}$ Deswaty Furqonita, ${ }^{\star 1}$ Ahmad A. Jusuf² \\ 'Departemen Anatomi, ${ }^{2}$ Departemen Histologi, Fakultas Kedokteran Universitas Indonesia \\ ${ }^{3}$ Departemen Anatomi, Fakultas Kedokteran Universitas Kristen Indonesia \\ *Penulis korespondensi: deswaty.furqonita@ui.ac.id
Diterima 29 Maret 2020; Disetujui 9 Agustus 2021 \\ https://doi.org/10.23886/ejki.9.64.110
}

\begin{abstract}
Abstrak
Ibu hamil yang terpapar bising akan memengaruhi janin yang dikandungnya bahkan memiliki efek negatif terhadap neurogenesis. Suara dari gelombang ritmis (musik) dapat meningkatkan neurogenesis yang berpengaruh langsung terhadap fungsi memori. Penelitian ini bertujuan untuk mengetahui efek positif gelombang ritmis untuk meredam atau menjadi terapi bagi bagian otak yang sebelumnya mendapat efek negatif gelombang monoton, dilihat dari peningkatan ekspresi densitas optik protein postsynapticdensity-95 dan waktu uji labirin T. Penelitian eksperimental ini dilakukan di laboratorium Developmental Biologi dan Patologi Anatomik Fakultas Kedokteran Universitas Indonesia pada bulan September 2018. Penelitian menggunakan 24 telur ayam yang difertilisasi dan dibagi empat kelompok: kelompok suara ritmis, monoton, gabungan (kombinasi suara monoton dan ritmis), dan kontrol. Telur yang sudah difertilisasi diinkubasi selama 21 hari dan dimiringkan secara otomatis tiap 4 jam. Dilakukan proses candling hari ke-3, ke-5, ke-10 dan ke-15 untuk menilai perkembangan embrio ayam. Hasil penelitian ini, terdapat perbedaan bermakna densitas optik protein postsynapticdensity 95 dan waktu uji labirin $T$ antara kelompok gabungan dengan kelompok ritmis dan monoton, namun tidak terjadi perbedaan bermakna dengan kelompok kontrol. Gelombang ritmis dapat mengurangi efek buruk gelombang monoton dan mengembalikannya menjadi sama dengan normal (kelompok kontrol).
\end{abstract}

Kata kunci: ritmis, monoton, kombinasi suara, memori, postsynapticdensity-95.

\section{Effect of Auditory Exposure combination of Monotonous and Rhythmic Waves on Postsynapticdensity-95 Expression on Neonatal Hippocampus}

\begin{abstract}
Pregnant women who are exposed to noise will affect the fetus they contain and even have a negative effect on neurogenesis. Sound from rhythmic waves (music) can increase neurogenesis which directly affects memory function. This study aims to determine the positive effect of rhythmic waves to dampen or become therapy for parts of the brain that previously received the negative effects of monotonous waves, seen from the increase in the expression of the optical density of the postsynapticdensity-95 protein and the labyrint $T$ test time. This experimental study was conducted in the Developmental Biology laboratory and Anatomic Pathology, Faculty of Medicine, University of Indonesia in September 2018. The study used 24 fertilized chicken eggs and divided into four groups: rhythmic, monotonous, combined (a combination of monotonous and rhythmic sounds), and control. Fertilized eggs are incubated for 21 days and automatically tilted every 4 hours. The candling process was carried out on the 3rd, 5th, 10th and 15th days to assess the development of chicken embryos. The results of this study, there was a significant difference in the optical density of the postsynaptic density protein 95 and the time of the $T$ labyrint test between the combined group and the rhythmic and monotonous group, but there was no significant difference with the control group. Rhythmic waves can reduce the bad effects of monotonous waves and return them to normal (control group).

Keywords: rhythmic, monotone, sound combination, memory, postsynaptic density-95.
\end{abstract}




\section{Pendahuluan}

Tingkat kebisingan tinggi dikaitkan dengan gangguan pendengaran. Efek bising terhadap kesehatan pertama kali diketahui di dunia pekerjaan sepertidipabriktenun. Ibu hamilyang bekerja di tempat bising akan berdampak terhadap janin. Berbagai tekanan (stres) fisik maupun emosional selama kehamilan menginduksi abnormalitas neonatus dan memperlambat perkembangan fungsi motorik. ${ }^{1}$ Selander et $\mathrm{al}^{2}$ melaporkan hubungan pajanan bising di tempat kerja selama kehamilan dan disfungsi pendengaran pada anak-anak yang dilahirkan. Suara bising adalah faktor stres terhadap embrio, sehingga mengganggu proses neurogenesis dan kemampuan spasial walaupun proses belajar yang diterima otak setelah lahir dapat merangsang remodeling struktur dendrit dan memperbaiki memori. ${ }^{3}$ Lingkungan bising memengaruhi sistem pendengaran karena menyebabkan kematian sel, pergeseran ambang batas, dan abnormalitas pengkodean neuronal di korteks auditori dan bagian otak lainnya seperti hipokampus. Hipokampus merupakan bagian otak yang lebih rentan terhadap kebisingan dibandingkan korteks auditori dilihat dari peningkatan stres oksidatif dan fosforilasi protein Tau. ${ }^{4}$

Postsynapticdensity protein-95 (PSD-95) berasal dari membran postsinaps pada sinaps eksitatori glutamatergik (glutamatergik excitatory sinapses). PSD-95 pada manusia dikodekan oleh gen disc large homolog 4 (DLG4) dan masuk dalam family membrane-associated guanylate kinase (MAGUK). Protein itu meregulasi hipokampus dan korteks di long term potentiation, berperan penting mengontrol kekuatan dan plastisitas sinaps yang bergantung pada aktivitas dan diperlukan pada proses belajar serta memori. Peningkatan ekspresi PSD-95 memfasilitasi potensial jangka panjang dan remodeling spina dendritik. Ekspresi PSD-95 berlebihan di neokorteks dan neuron hipokampus meningkatkan gabungan $\alpha$-amino-3-hydroxy5-methyl-4-isoxazolepropionic acid receptor (AMPAR) di sinaps untuk membantu potensiasi jangka panjang yang bergantung pada $N$-methyl-daspartat receptor (NMDAR). AMPAR dan NMDAR merupakan upregulator untuk PSD-95. ${ }^{5}$

Pada pajanan suara musik sitar $65 \mathrm{~dB}$ kepada fetus ayam didapatkan peningkatan kadar PSD 95 yang lebih tinggi dibandingkan yang dipajankan suara induknya (species specific calls) dan tanpa pajanan. ${ }^{6}$ Anak ayam yang diberikan pajanan musik memiliki kadar PSD-95 lebih tinggi dibandingkan anak ayam yang diberi pajanan bising pada prenatal. ${ }^{3}$ Ayam dipilih sebagai hewan coba karena sistem pendengaran embrio ayam mengalami maturasi lebih awal dari sistem sensoris yang lain. ${ }^{7}$ Selain itu ayam cepat menjadi dewasa, sistem auditori yang baik saat lahir seperti manusia, dan dapat merespons suara yang ditransmisikan melalui udara selama embrio. ${ }^{8}$

Penelitian ini bertujuan untuk melihat efek positif dari gelombang ritmis (musik) dalam meredam atau sebagai terapi otak yang mendapat efek negatif dari gelombang monoton (bising) yang dinilai dari ekspresi protein PSD-95 dan uji labirin T.

\section{Metode}

Desain penelitian adalah eksperimental post-test design yang dilakukan di Laboratorium Developmental Biology dan Patologi Anatomik FKUI pada bulan September 2018. Objek penelitian adalah telur ayam Gallus gallus domesticus yang difertilisasi di Balai Penelitian Ternak (BALITNAK) Ciawi. Kriteria inklusi adalah telur tetas sehat, yaitu berat $50-65 \mathrm{~g}$, bentuk normal, warna kulit agak gelap, dan umur telur tidak lebih dari 1 minggu.

Sebanyak 24 telur ayam dibagi 4 kelompok yaitu: (1) Kelompok kontrol, tidak mendapat pajanan suara; (2) Kelompok ritmis, yang mendapatkan pajanan gelombang ritmis; (3) Kelompok monoton, diberikan pajanan gelombang monoton $110 \mathrm{~dB}$; (4) Kelompok gabungan monoton dan ritmis, diberikan pajanan dengan gelombang monoton terlebih dahulu, lalu dipajan lagi dengan gelombang ritmis.

Penelitian ini telah lolos kaji etik dari Komite Etik Penelitian Fakultas Kedokteran Universitas Indonesia (No. 0152/UN2.F1/ETIK/2018) dan surat perpanjangan ND-475/ UN2.F1/ETIK/ PPM.00.02/2019.

\section{Proses Inkubasi}

Telur yang sudah difertilisasi diinkubasi di inkubator dengan suhu $37{ }^{\circ} \mathrm{C} \pm 2{ }^{\circ} \mathrm{C}\left(35-39{ }^{\circ} \mathrm{C}\right)$ dan kelembapan $70 \%(68-72 \%)$ selama 21 hari. Telur dimiringkan secara otomatis tiap 4 jam. Proses candling dilakukan hari ke-3, ke-5, ke10 , ke-15 untuk menilai perkembangan embrio (Gambar 1). Proses candling bertujuan mendeteksi gangguan pertumbuhan embrio, namun tidak dapat melihat tahapan neurogenesis sistem saraf pusat embrio. Candling hari ke-3 untuk melihat fertilitas sedangkan candling hari ke- 5 , ke-10, ke-15 untuk melihat gangguan perkembangan embrio dengan memperhatikan ada tidaknya cincin darah (ring blood) di sekitar yolk sac. Jika terdapat telur infertil pada hari ke-3 atau ring blood hari ke-5, ke-10, ke-15, telur dieksklusi guna menghindari penyebaran infeksi. ${ }^{9}$ 

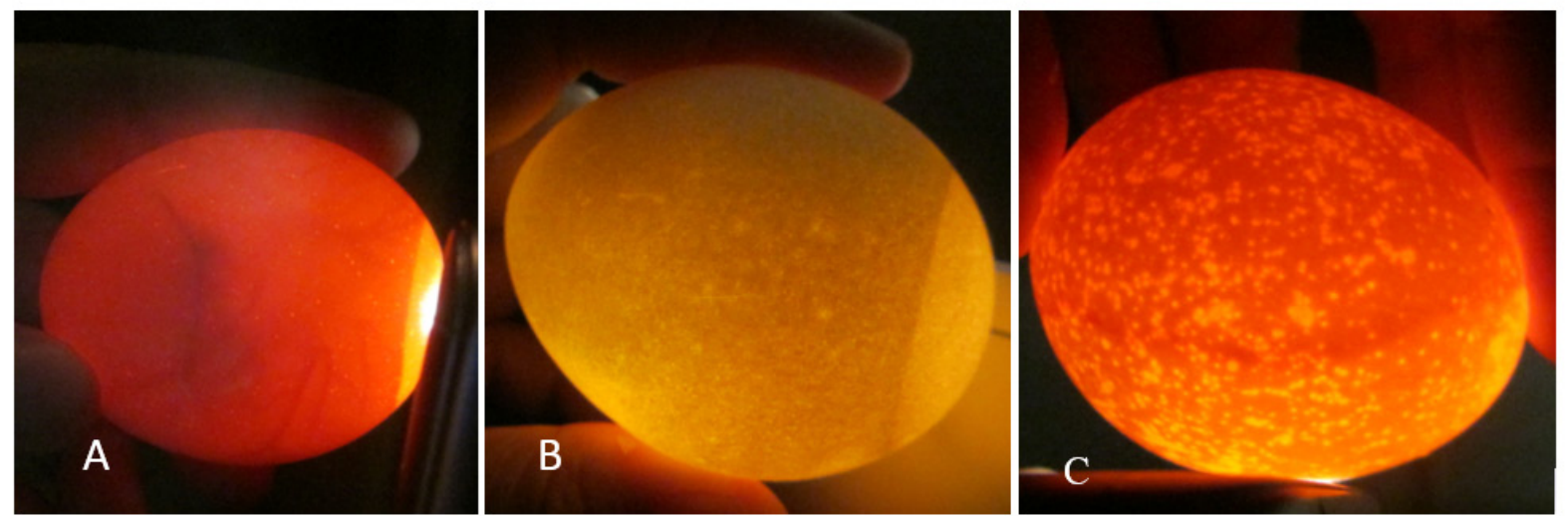

Gambar 1. Candling Telur. A. Embrio berkembang baik, tampak anyaman pembuluh darah di sekitar embrio. B. Telur tanpa embrio. C. Embrio tidak berkembang, terdapat cincin merah melingkar.

Telur diletakkan di inkubator dengan built-in speaker. Kelompok suara ritmis dipajankan musik klasik berjudul Eine Kleine Nachtmusic Serenade ${ }^{10}$ in G major No.13 K.525-I, allegro dengan intensitas $65 \mathrm{~dB}$. Kelompok suara monoton dipajankan suara mesin penggiling daging yang direkam pada jarak 1,5 meter dari sumber suara dengan intensitas $110 \mathrm{~dB}$. Kelompok gabungan dipajankan suara monoton $110 \mathrm{~dB}$ terlebih dahulu selama 15 menit diikuti suara ritmis $65 \mathrm{~dB} 15$ menit. Seluruh pajanan suara memiliki frekuensi dalam rentang speciesspecific calls induk ayam 100-6300 Hz. Pajanan suara dengan siklus 15 menit tiap jam dan 45 menit hening, selama 24 jam sejak embrio hari ke10 (E10) sampai telur menetas. ${ }^{5}$ Pada kelompok gabungan, digunakan 2 alat berbeda yaitu amplifier dan speaker portable. Alat diatur dengan cara 15 menit suara monoton dan 15 menit suara ritmis bergantian, 30 menit sisanya hening. Kelompok kontrol tidak dipajankan suara apapun.

\section{Uji Labirin T}

Uji labirin $T$ dilakukan untuk mengevaluasi orientasi spasial, kemampuan belajar dan memori anak ayam berusia 1 hari/PH1 (post hatch 1). Sebelum pelatihan, semua anak ayam ditempatkan di kandang selama satu jam. Setelah itu diambil seekor anak ayam dan ditempatkan di kotak isolasi. Waktu untuk anak ayam keluar dari kotak isolasi yaitu isolation time (IT), waktu eksplorasi (exploration time/ET) di lengan-T dan total waktu (total time/TT) untuk mencapai target, direkam dengan stopwatch. Percobaan dilakukan tiga kali dengan interval 10 menit antara setiap percobaan untuk setiap anak ayam. Kemampuan anak ayam menghafal tugas dinilai dengan mengulangi T-maze 24 jam setelah percobaan terakhir (total time memory/TTM).

\section{Pengambilan Jaringan dan Pewarnaan Imunohistokimia}

Neonatus ayam yang telah menjalani uji memori didekapitasi untuk diambil jaringan otaknya, yaitu serebrum. Setelah kranium dibuka, serebrum dipisahkan dari serebelum. Serebrum dipotong koronal pada 1/3 anterior, sedangkan 2/3 posterior dibiarkan utuh untuk diproses dengan pewarnaan imunohistokimia. Kontrol positif diambil dari serebelum ayam.

\section{Perhitungan Densitas Optik}

Jaringan yang diwarnai secara imunohistokimia difoto dengan mikroskop terintegrasi kamera LeicaDM 750 pembesaran 40x, 100x, dan 400x dengan jumlah pixel 5038848. Tiap sediaan hipokampus difoto dengan pembesaran 400x. Densitas optik dihitung dengan software imageJ. Densitas optik dipilih karena paling objektif dalam menilai ekspresi protein PSD-95. Semakin tinggi kadar densitas optik, semakin tinggi kadar PSD95 dalam sel, karena software menilai densitas warna yang diekspresikan oleh antibodi PSD-95 di sitoplasma neuron hipokampus. Peningkatan ekspresi protein PSD-95 memengaruhi pembentukan plastisitas sinaps yang berhubungan dengan peningkatan fungsi memori. ${ }^{3}$

Ekspresi protein PSD 95 di hipokampus berperan penting dalam plastisitas neuronal dan menjadi dasar keberhasilan proses belajar dan memori pada neonatus ayam. ${ }^{3}$ Persentase terdiri atas sel positif intensitas kuat, sedang, lemah, serta persentase sel negatif. Skor densitas optik dihitung dengan metode IHC optical density score, yaitu: $\{$ (persentase positif kuat $\times 4)+($ persentase positif sedang $\times 3)+($ persentase positif lemah $\times 2)$ $+($ persentase negatif $\times 1)\} / 100$ 
Data dianalisis secara deskriptif berupa foto jaringan yang diwarnai secara imunohistokimia dan data uji labirin T. Protein PSD-95 di hipokampus dinilai dengan software ImageJ. Data dianalisis dengan program SPSS versi 20.0, lalu diuji normalitas, dilanjutkan uji one way ANOVA jika data berdistribusi normal atau uji Kruskal-Wallis jika data tidak berdistribusi normal.

\section{Hasil \\ Imunohistokimia Protein Postsynapticdensity-95}

Hipokampus neonatus ayam memperlihatkan imunoreaktivitas PSD-95 di sitoplasma sel neuron. Imunoreaktivitas pada kelompok gabungan sama kuat dengan kelompok kontrol, tetapi tidak lebih kuat dari kelompok ritmis yang sangat kuat reaktivitasnya (Gambar2). Kelompok monoton imunoreaktivitasnya lemah dibandingkan kelompok gabungan.
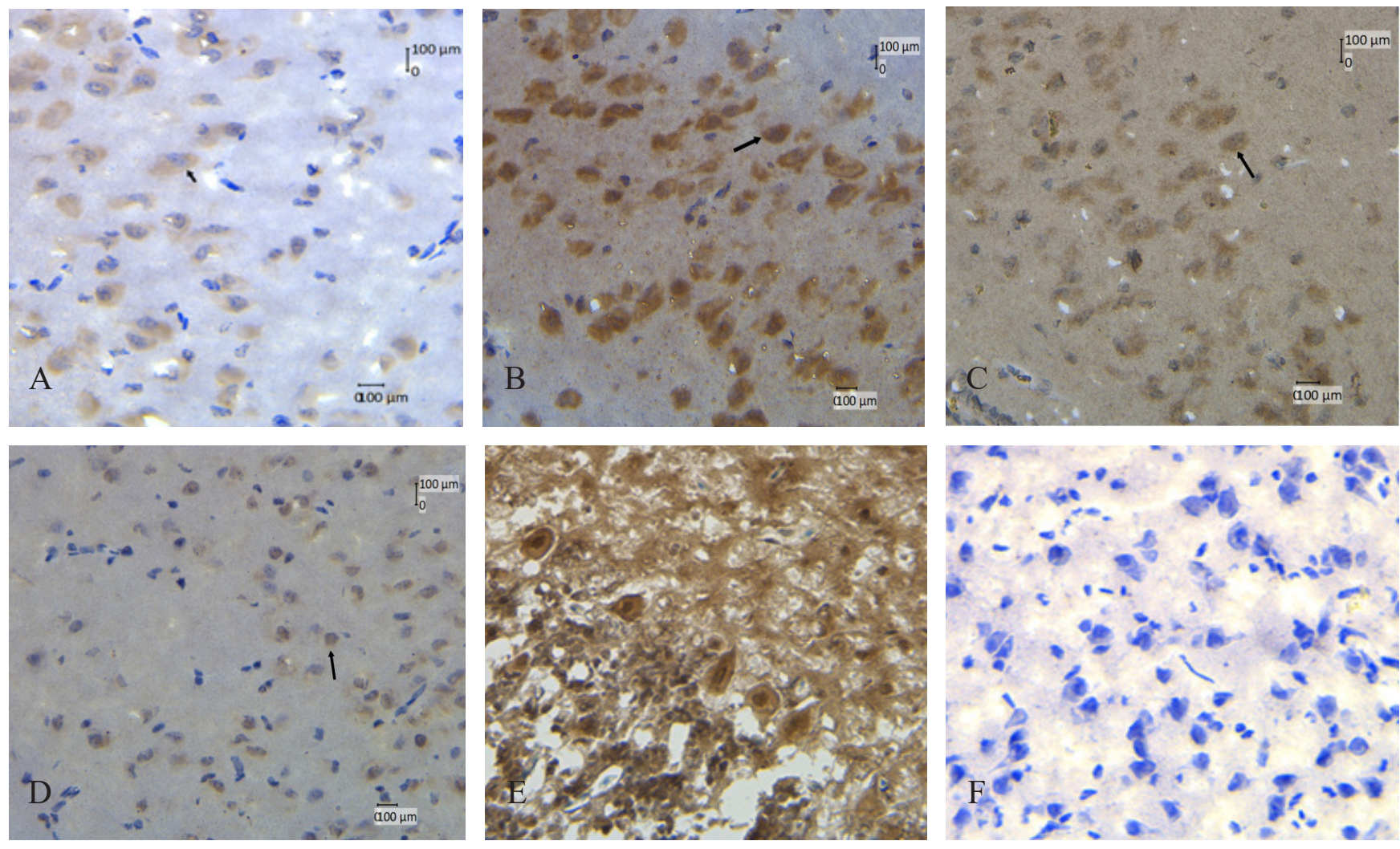

Gambar 2. Pulasan Imunohistokimia Protein PSD 95. Tampak imunostaining sitoplasma neuron (anak panah) yang kuat pada Gambar B (ritmis). Imunostaining kelompok C (gabungan) lebih lemah dibandingkan B (ritmis) tetapi lebih kuat dibandingkan $D$ (monoton), dengan kekuatan yang sama terhadap A (kontrol). A (kontrol), B (ritmis), C (gabungan), D (monoton), E (kontrol positif), F (kontrol negatif). Skala 1:100 $\mu \mathrm{m}$.

Tidak ada perbedaan bermakna (uji levene, $p>0,05)$ pada densitas optik hipokampus otak kiri dan kanan, namun berbeda bermakna pada densitas optik protein PSD-95 antar kelompok (uji one way Anova, $\mathrm{p}<0,001$ ). Pada kelompok gabungan terdapat perbedaan bermakna densitas optik dengan kelompok ritmis (uji post hoc bonferroni $\mathrm{p}=0,002$ ) dan kelompok monoton (uji post hoc bonferroni $\mathrm{p}<0,001$ ). Namun, pada kelompok gabungan, densitas optik tidak berbeda bermakna dengan kelompok kontrol (uji post hoc Bonferroni $p=1,000$ ) (Gambar 3). 


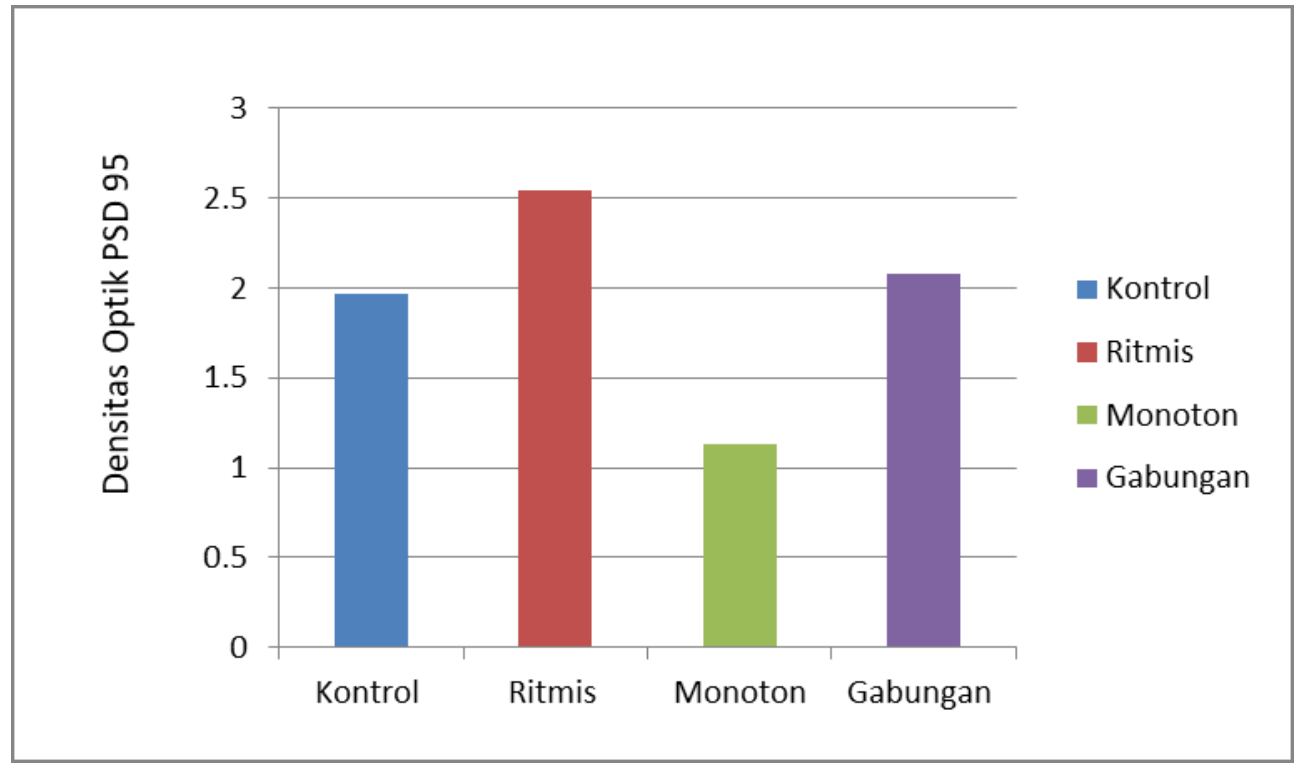

Gambar 3. Diagram batang Densitas Optik PSD 95 pada Masing-masing Kelompok. *Terdapat perbedaan bermakna antara kelompok gabungan dibandingkan kelompok ritmis dan monoton, tetapi tidak berbeda bermakna terhadap kelompok kontrol.

\section{Uji Labirin T untuk Menilai Memori Spasial}

Pada uji labirin T terdapat perbedaan bermakna pada IBL, ET, dan TT pada masing-masing kelompok (one way anova, $p<0,001$ ). Pada Gambar 4 dapat dilihat kelompok gabungan memiliki perbedaan waktu uji labirin $\mathrm{T}$ yang bermakna dibandingkan kelompok ritmis dan monoton, tetapi tidak berbeda bermakna terhadap kelompok kontrol (uji post hoc benferonni $p=1,000$ ).
Perbandingan antara TT1 sampai TT3 berbeda bermakna (uji repeated ANOVA measurement, $p<0,001$ ), Selanjutnya dilakukan uji untuk membandingkan IT, ET dan TT dan didapatkan perbedaan bermakna (paired wise comparison, $p<0,001)$. Pada post hocgreenhouse-geisser test of within subject effect, hasil IT, ET dan TT adalah $p<0,001$. Jadi terdapat penurunan waktu yang dibutuhkan oleh neonatus ayam dari TT1 sampai dengan TT3 pada tiap-tiap kelompok (Gambar 4).

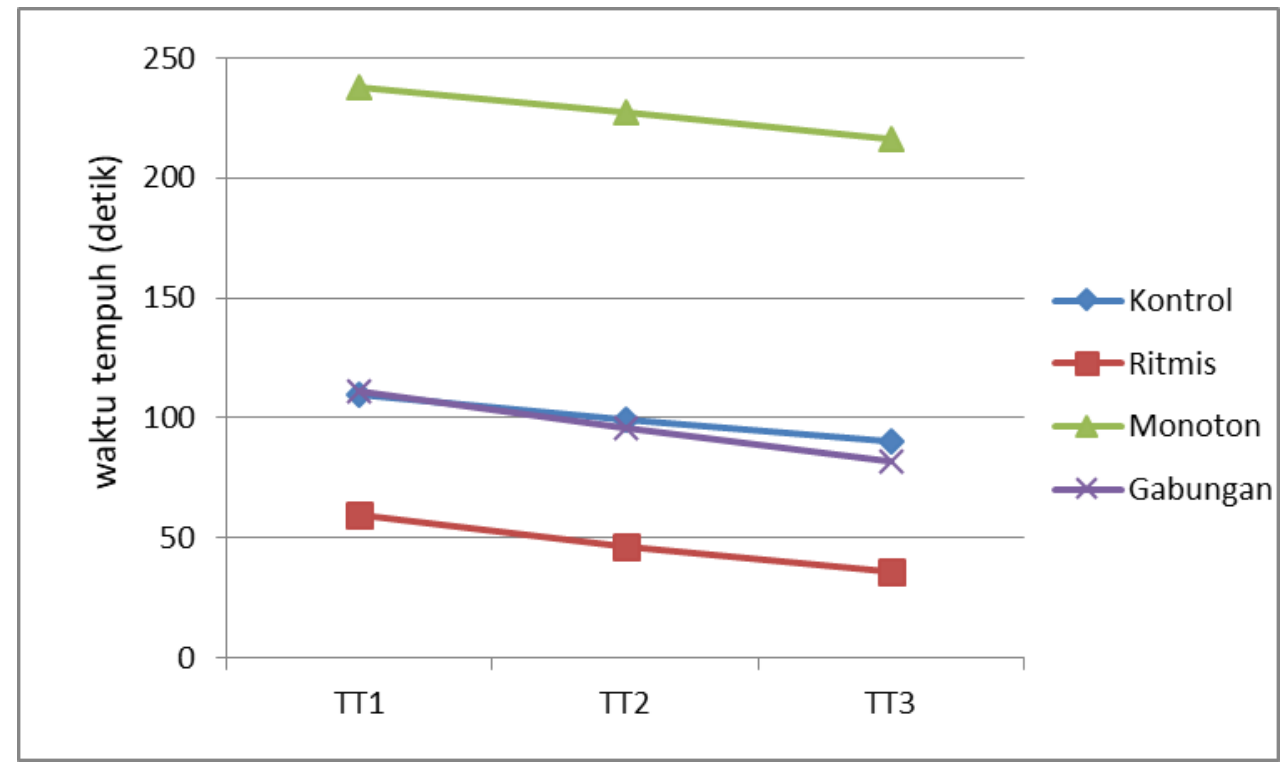

Gambar 4. Grafik Waktu Uji 1-3 untuk Menilai Orientasi Spasial dan Proses Pembelajaran antar Kelompok. TT1: Total Time Uji Orientasi 1; TT2: Total Time Uji Orientasi 2; TT3: Total Time Uji Orientasi 3 
Pada Gambar 5 diperlihatkan grafik perbandingan TT3 dengan TTM. Pada seluruh kelompok penelitian tampak penurunan waktu tempuh dari TT3 ke TTM. Kelompok gabungan mempunyai TTM lebih lama daripada kelompok musik tetapi lebih cepat waktu tempuhnya dibandingkan kelompok bising. Kelompok gabungan mempunyai waktu tempuh TTM yang tidak berbeda bermakna dibandingkan kelompok kontrol.

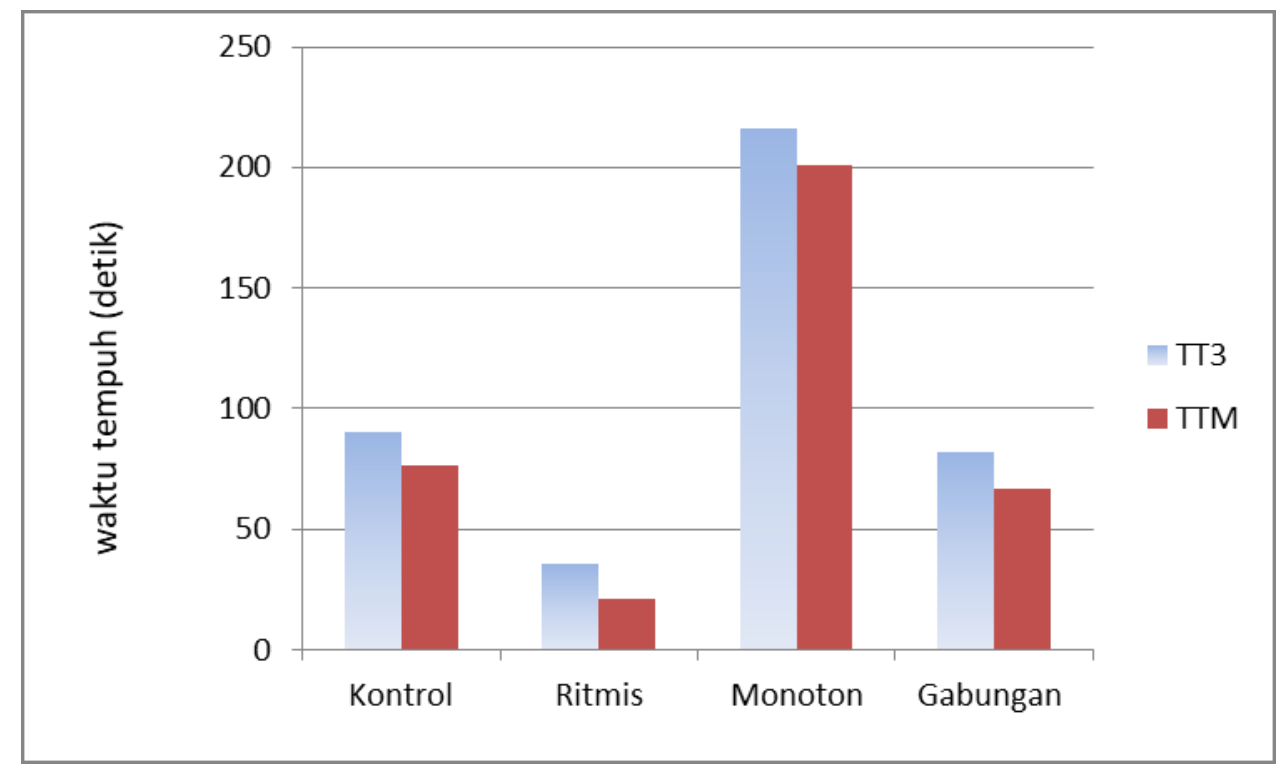

Gambar 5. Diagram batang Waktu Keseluruhan (Total Time 3/TT3) Uji Ketiga dan Waktu Keseluruhan Memori (Total Time Memory/TTM)

\section{Diskusi}

Pajanan auditorik memengaruhi bagian otak non-auditorik seperti sistem limbik. Amigadala dan hipokampus adalah dua regio mayor limbik yang menerima input neuronal secara langsung dan tidak langsung dari pusat sistem auditori. PSD-95 penting untuk pematangan sinaps dan fungsi sinaptik stabilisasi dan plastisitas sinaps. ${ }^{11}$ Pematangan awal dan stabilitas sinapsis dapat terjadi di hipokampus neonatus ayam yang terstimulasi suara musik yang dipajankan saat prenatal.

Peningkatan ekspresi protein PSD-95 pada kelompok yang dipajankan auditorik prenatal berperan penting pada plastisitas yang bergantung pada aktivitas (activity dependent plasticity). Ekspresi berlebih PSD-95 di neokortikal dan neuron hipokampus meningkatkan penggabungan AMPAR di sinap yang membantu potensiasi jangka panjang bergantung pada reseptor NMDA.6,12 Chaudury et $\mathrm{al}^{6}$ melaporkan bahwa pada neonatus ayam, protein PSD-95 muncul lebih awal (pada E16) di hipokampus setelah terpajan stimulasi pendengaran prenatal. Ekspresi protein PSD 95 meningkat pada neonatus ayam yang dipajankan suara musik sitar $65 \mathrm{~dB}$ dan suara induknya dibandingkan kontrol.
Gelombang monoton dengan intensitas tinggi $110 \mathrm{~dB}$ dapat menyebabkan stres pada neonatus dan terlepasnya hormon stres, (noradrenalin). Kadar noradrenalin plasma meningkat sangat tinggi pada neonatus yang dipajankan gelombang monoton intensitas tinggi $110 \mathrm{~dB}$. Noradrenalin yang tinggi mengganggu kemampuan spasial dan memori pada neonatus ayam. ${ }^{3}$ Pajanan gelombang suara monoton memengaruhi neurogenesis hipokampus dan long term potentiation (LTP) dengan memengaruhi plastisitas struktural serta efek negatif terhadap proses belajar dan memori. ${ }^{3}$

Pada penelitian ini kelompok gabungan yang dipajankan kombinasi gelombang ritmis $65 \mathrm{db}$ dan monoton $110 \mathrm{~dB}$ mempunyai densitas optik protein PSD-95 yang tidak berbeda bermakna dengan kontrol karena pajanan gelombang ritmis $65 \mathrm{~dB}$ dapat memodulasi dan mengurangi efek negatif gelombang monoton berintensitas tinggi $110 \mathrm{~dB}$. Hal tersebut disebabkan signaling yang distimulasi oleh suara prenatal meningkatkan kepadatan sinaptik dan protein sinaptik termasuk PSD 95 hipokampus ayam.

Pajanan musik sebagai stimulus auditorik eksternal meningkatkan calcium binding protein (CaBPs) yang memicu aktivitas jalur sinyal $\mathrm{Ca} 2+$ dependent yang menyebabkan up regulation 
cAMP respons elemen binding (CREB) sehingga meningkatkan densitas sinaptik dan protein sinaps termasuk PSD-95. ${ }^{7}$ Aktivasi jalur sinyal juga menyebabkan pertumbuhan hubungan sinapssinaps baru di hipokampus yang berpengaruh langsung pada pembentukan memori. Peningkatan protein mengurangi efek buruk gelombang monoton berintensitas tinggi. Gelombang ritmis berintensitas $65 \mathrm{~dB}$ merupakan suara percakapan sehari-hari dan tidak bising sehingga enak didengar manusia. Pada penelitian ini, kelompok gabungan dengan gelombang berintensitas $65 \mathrm{~dB}$ mampu menahan stres dari pajanan gelombang monoton intensitas tinggi $(110 \mathrm{~dB})$ karena gelombang ritmis bersifat menenangkan dan memberi efek positif bagi sistem limbik sebagai pusat emosi. ${ }^{13}$

Protein lain yang berhubungan dengan pajanan kombinasi suara ritmis dan monoton adalah sinaptofisin di batang otak dan korteks cerebri, serta protein BDNF di hipokampus. Ekspresi sinaptofisin pada kelompok gabungan (gelombang monoton $110 \mathrm{~dB}$ dan ritmis $110 \mathrm{~dB}$ ) dapat menyamai ekspresi sinaptofisin di kelompok kontrol.

Penelitian ekspresi sinaptofisin di korteks serebri pada kelompok kombinasi gelombang monoton intensitas tinggi $110 \mathrm{~dB}$ dengan gelombang ritmis intensitas sedang $65 \mathrm{~dB}$, menunjukkan kelompok gabungan memberikan ekspresi sinaptofisin paling tinggi bahkan melampaui intensitas $110 \mathrm{~dB}$. Penelitian lain menunjukkan pada kelompok gabungan yang diberikan gelombang suara ritmis dengan intensitas tinggi $110 \mathrm{~dB}$ dan gelombang monoton $110 \mathrm{~dB}$, ekspresi brain derived neurotrophic factor (BDNF) pada kelompok gabungan tidak berbeda bermakna dengan kelompok kontrol.

Labirin $\mathrm{T}$ dirancang untuk memperkirakan kinerja pembelajaran spasial hewan coba (neonatus ayam). ${ }^{3}$ Pada neonatus ayam, rangsangan pendengaran berirama yang relevan memfasilitasi memori untuk pembelajaran diskriminatif yang dihasilkan oleh noradrenalin mediated arousal. ${ }^{14}$ Ayam yang distimulasi musik, menavigasi labirin lebih cepat dari percobaan pertama dibandingkan 2 kelompok lainnya. Stimulasi akustik juga memengaruhi aktivitas lokomotor dan bertanggung jawab atas navigasi cepat anak ayam yang terpajan. ${ }^{7}$

Pada penelitian ini waktu yang diperlukan untuk keluar dari isolation box, T-arm dan waktu yang diperlukan untuk keluar dari labirin $T$ pada semua kelompok mengalami penurunan waktu, yang berarti semua kelompok mengalami proses pembelajaran. Namun, di antara ke-4 kelompok tersebut terdapat perbedaan waktu yaitu waktu tempuh paling cepat adalah kelompok ritmis yang berbeda bermakna dengan kelompok gabungan, monoton dan kontrol. Waktu tempuh paling lama adalah pada kelompok monoton, yang berbeda bermakna dengan kelompok gabungan dan kontrol. Pada kelompok gabungan dan kontrol tidak ada perbedaan bermakna. Hal itu sesuai dengan teori yang menyatakan bahwa gelombang ritmis memengaruhi kemampuan spasial hewan coba. ${ }^{3,6}$ Gelombang monoton menurunkan kemampuan spasial hewan coba karena efek peningkatan kadar noradrenalin secara berlebihan mengaktivasi reseptor $\alpha 1$ adrenergik sehingga menghambat pembentukan memori dan menurunkan kemampuan spasial. ${ }^{3}$

Untukpenilaianmemoriterlihatsemuakelompok mempunyai waktu yang berbeda bermakna antara uji ke-3 dan uji ke-4 (memori), walaupun semua kelompok mengalami penurunan waktu dari TT3 ke TTM. Hal tersebut memperlihatkan bahwa semua kelompok mengalami proses belajar yang baik. Kelompok monoton mempunyai penurunan waktu pada uji TTM yang berarti kemampuan memori kelompok monoton berkembang walaupun tidak dapat menandingi memori kelompok ritmis, gabungan atau kontrol. Kelompok gabungan tidak berbeda bermakna dengan kontrol, karena pajanan ritmis yang diberikan dapat mengurangi atau menahan efek buruk yang ditimbulkan oleh gelombang monoton.

Bising dengan intensitas tinggi $110 \mathrm{~dB}$ dapat menyebabkan stres pada neonatus, yang menyebabkan dikeluarkannya hormon stres salah satunya noradrenalin. Pada penelitian pajanan suara yang menilai kadar hormon noradrenalin pada plasma, noradrenalin plasma meningkat sangat tinggi pada kelompok neonatus yang dipajan bising berintensitas $110 \mathrm{~dB}$. Noradrenalin kadar tinggi mengganggu kemampuan spasial dan memori neonatus ayam. ${ }^{3}$

Pada penelitian ini hasil uji labirin $T$ berhubungan dengan optical density protein PSD95. Kelompok ritmis dengan kepadatan optik tinggi menghasilkan kemampuan spasial dan memori paling baik sedangkan kelompok monoton dengan kepadatan optik paling rendah menghasilkan kemampuan spasial dan memori paling rendah. Hal itu sesuai dengan teori bahwa perbedaan ekspresi protein PSD-95 hipokampus penting pada plastisitas neuronal dan dapat menjadi dasar keberhasilan proses belajar serta memori neonatus ayam. ${ }^{3}$ 


\section{Kesimpulan}

Terdapat hubungan densitas optik protein PSD-95 dan uji memori pada kelompok gabungan yang terpajan gelombang ritmis dan monoton dibandingkan dengan kelompok monoton. Pajanan gabungan gelombang monoton $110 \mathrm{~dB}$ dan gelombang ritmis $65 \mathrm{~dB}$ meningkatkan ekspresi protein PSD 95 di hipokampus menjadi sama dengan kontrol. Dengan peningkatan ekspresi densitas optik PSD-95 dan waktu uji labirin T, gelombang ritmis dapat mengurangi efek buruk gelombang monoton dan mengembalikannya menjadi sama dengan normal sehingga dapat menjadi dasar terapi bagi bagian otak yang sudah mendapat efek negatif dari gelombang monoton.

\section{Daftar Pustaka}

1. Kim CH, Lee SC, Shin JW, Chung KJ, Lee SH, Shin $\mathrm{MS}$, et al. Exposure to music and noise during pregnancy influences neurogenesis and thickness in motor and somatosensory cortex of rat pups. Int Neurobiology J Med. 2013;17107-13. doi: 10.5213/ inj.2013.17.3.107.

2. Selander J, Albin M, Rosenhall RL, Lewne M, Gustavsson P. Maternal occupational exposure to noise during pregnancy and hearing dysfunction children: a nation wide prospective cohort study in Sweden. Environ Health Perspect. 2016;12485560. doi: 10.1289/ehp.1509874.

3. Sanyal T, Kumar V, Nag TC, Jain S, Sreenivas V, Wadhwa S. Prenatal loud music and noise: differential impact on physiological arousal, hippocampal synapto-genesis and spatial behavior in one day-old chicks. PLoS ONE. 2013;8:e67347. doi: 10.1371/journal.pone.0067347.

4. Cheng L, Wang SH, Huang Y, Liao XM. The hippocampus may be more susceptible to environmental noise than the auditory cortex. Hearing research. 2016;333:93-7 doi: 10.1016/j. heares.2016.01.001.

5. W H Satriani, S Redjeki and N T Kartinah. Effect of complex aerobic physical exercise on PSD-95 in the hippocampus and on cognitive function in juvenile mice. J Physiol. 2017; 884-012023. doi :10.1088/1742-6596/884/1/012023.
6. Chaudury S, Jain S, Wadhwa S. Expression of synaptic protein in the hippocampus and spatial learning in chick following prenatal auditory stimulation. J Neuoroscience. 2010;32:114-24. doi: 10.1159/000279758.

7. Chaudury S, Nag TC, Jain S, Wadhwa S. Role of sound stimulation in reprogramming brain connectivity. J.Biosci. 2013;38:605-14. doi: 10.1007/ s12038-013-9341-8.

8. Alladi P. Roy TS, Singh N, Wadhwa S. Developmentally regulated expression of c-fos and c-jun in the brainstem auditory nuclei of Gallus domesticus is modified by prenatal auditory enrichment. Jurnal of Neurobiology. 2005;62:92105. doi: 10.1002/neu.20071.

9. Vargas R. Merging manual and automated egg candling: a safety and social solution. Enfoque UTE. 2018;9;70-6. doi: 10.29019/enfoqueute.v9n2.292

10. Papoutsoglou SE, Karakatsouli N, Louizos E, Chadio $S$, Kalogiannis D, et al. Effect of Mozart's music (romanze-andante of "Eine Kleine Nacht Musik", sol major, K525) stimulus on common carp (Cyprinus carpio) physiology under different light conditions. Aquacult Eng. 2007;36:61-72. doi: 10.1016/j. aquaeng.2006.07.001.

11. Ehrlich I, Klein M, Rumpel S, Malinow R. PSD-95 is required for activity-driven synapse stabilization. Proc Nat Acad Sci,USA. 2007;104:4176-81. doi: 10.1073/pnas.0609307104.

12. Ehrlich I, Malinow R. Postsynaptic density 95 controls ampa receptor incorporation during longterm potentiation and experience-driven synaptic plasticity. J Neurosci. 2004;24:916-27. doi: 10.1523/ JNEUROSCI.4733-03.2004.

13. Chanda ML, Levitin DJ. The neurochemistry of music. Trends Cogn Sci. 2013;17: 179-93. doi: 10.1016/j.tics.2013.02.007.

14. Field SE, Rickard NS, Toukhsati SR, Gibbs ME. Maternal hen calls modulate memory formation in one day-old chick: the role of noradrenalin. Neurobiol Learn Mem. 2007;88:321-30. doi: 10.1016/j. nIm.2007.04.001. 